\title{
Питання психології
}

УДК 321.02:159.955

DOI: $10.33099 / 2617-6858-20-58-5-72-79$

Камшеко К. І. аспірант, кафедра соиіальної психології факультету психології, КНУ імені Тараса Шевченка https://orcid.org/0000-0001-7943-2620

Tраверсе Т. М. доктор психологічних наук, дочент, КНУ імені Тараса Шевченка https://orcid.org/0000-0002-9031-1173

\section{ЗАДОВОЛЕНІСТЬ ЖИТТЯМ ЯК СКЛАДОВА СУБ'ЄКТИВНОГО БЛАГОПОЛУЧЧЯ ОСІБ ІЗ ГОМОСЕКСУАЛЬНОЮ ОРІЕНТАЦЕЮ}

\begin{abstract}
Поняття задоволеності життям пов'язують із суб'єктивним благополуччям особистості, $з$ позитивними та негативними емоціями. Йдеться про суб' єктивне емоційне ставлення до змістовної й змістової сторони подій і явищ життя осіб із гомо- та гетеросексуальними орієнтачіяли.

Ключові слова: ідентичність геїв та чоловіків; суб'єктивне благополуччя лесбійок та гомосексуалів; суб'єктивне благополуччя гетеросексуалів; задоволеність життям.
\end{abstract}

Вступ. Благополуччя стало мірилом національної політики, критерієм міжнародних рейтингів тощо. Вчені зазначають, що переживання благополуччя можливе в умовах різної складності, у, так званих, складних й ускладнених умовах (навіть при незадоволенні базових потреб, переживанні страждань тощо). Це відбувається завдяки перебудові ціннісносмислової сфери як соціуму, так і окремої людини. Така ситуація продукує чимало проблем, зокрема, визначення змісту та критеріїв благополуччя, розробки технологій, так званого, управління різними видами й типами благополуччя (визначення необхідної і достатньої його міри, рівня, співвідношення можливих i наявних форм, тощо). Це пов'язане 3 актуалізацісю відповідних внутрішніх ресурсів людини задля боротьби 3 безпорадністю, що породжується умовами життя навіть в розвинених країнах (наприклад, теракти, аварії, корупція тощо). У складних соціальних й екологічних умовах головною метою людини все більше стає виживання.

Постановка проблеми. Динамічні зміни у вітчизняному соціумі зумовлюють потребу в дослідженні тих явищ, які є детермінантами позитивного функціонування людини. Йдеться про благополуччя, про ті фактори, які сприяють визначенню життєвих перспектив, цінностей, особистісної автономії, сприяють актуалізації їі внутрішніх ресурсів, що допомагають протидіяти негативному впливу середовища. Незворотня прийдешність кардинально нового майбутнього продукує новітні трансформації суспільства, що своєю чергою, пов'язане зі зміною культурних кодів, легітимізацією інакших субкультур і спільнот, ціннісних зсувів і т. П. Все це зумовлює суттєві зміни у переживанні людиною свого буття, психологічного благополуччя чи неблагополуччя. Проблема суб'єктивного благополуччя, його значущості в різних аспектах життя особистості набуває особливої актуальності для осіб із гомосексуальною орієнтацією.

Теоретичне підгрунтя. Феномен суб'єктивного благополуччя особистості всебічно вивчається і досліджується у світовій психологічній науці, насамперед, у зв'язку 3 вивченням станів оптимального функціонування людини. У наукових працях для визначення позитивного функціонування особистості вживають поняття «щастя», «суб'єктивне благополуччя», «соціальне благополуччя», «психологічне благополуччя», «задоволеність життям», «процвітання» «психічне здоров'я», «емоційний комфорт» тощо. Ці феномени описують цілісну психологічну реальність, іiі різнобічність, що відбито в методологічних традиціях дослідження благополуччя, особливостях його концептуалізації, а отже в його змістовних, змістових та ін. характеристиках. 


\section{Питання психології}

Як відомо, весь сучасний доробок щодо проблеми психологічного благополуччя особистості вчені формулюють у двох основних напрямах щодо його трактування гедоністичному та евдемонічному. У контексті гедоністичного напряму йдеться про задоволення потреб у різних сферах життя як джерела психологічного благополуччя, яке насамперед пов'язане із задоволеністю життя, відсутністю негативного афекту та наявністю позитивних емоцій (Н. Бредбурн 1990, Е. Дінер, 1996 та ін.). У контексті евдемоністичного підходу генезою психологічного благополуччя $\epsilon$ задоволення базових потреб особистості, яке детермінується актуальним соціальним контекстом. Йдеться про ті чинники, процеси і умови, які здатні актуалізувати генетично заданий потенціал особистості. Це, своєю чергою, пов'язане з різними видами здоров'я людини та 3 особливостями іï особистісного зростання. В такому трактуванні психологічне благополуччя $\epsilon$ результатом розкриття суб'єктивного творчого потенціалу особистості, самореалізацією іiі неповторної індивідуальності, де визначальними $\epsilon$ самодетермінація, компетентність та позитивні стосунки (Deci, Rean, 2000).

Отже, в існуючих підходах до визначення змісту психологічного благополуччя можна виокремити твірні аспекти щодо його трактування, а саме як: стан (Н. Бредбурн 1990, Е. Дінер, 1996 та ін.), процес (Deci, Rean, 2000), результат (К. Л. М. Кейєс, 1998 та iн.).

За змістом компонентів психологічного благополуччя в наявних методологічних традиціях можна виокремити, так звані, види благополуччя за різними критеріями, а саме: a) за спрямованістю на предметну сферу (соціальне, фінансове, фізичне, професійне, благополуччя в середовищі проживання) (Рат, 2011; Хартер, 2011; Lyubomirsky, Sheldon, Schkade, 2005; Seligman, Csikszentmihalyi, 2000); б) за змістом задоволення (собою, діяльністю, відносинами, життям тощо) (Шаміонов, 2004).

Про суб'єктивне благополуччя йдеться в контексті глобалізаційних процесів. Вчені дійшли висновку, що глобалізація задає нові контексти для самовираження та трансформування своєї ідентичності тим особам, ідентичність яких не $\epsilon$ традиційною/нормативною для окремих великих спільнот. У тих субкультурах, де нормативно маскулинність пов'язується із гетеросексуальністю, ідентичність геїв та чоловіків «знаходиться під загрозою» (Кос, Vignoles, 2018). Зокрема, існує зв'язок між прийняттям ідентичності «громадянина світу» та підвищенням сумісності між ідентичностями геїв та чоловіків, тобто інтеграція цих ідентичностей здатна підвищити суб'єктивне благополуччя осіб із гомосексуальною орієнтацією, створивши, так званий, позитивний соціальний контекст для геїв. Тому, благополуччя розрізняють за статтю - суб'єктивне соціальне благополуччя гетеросексуалів (Данильченко, 2016; Пахоль, 2020; Serdiuk, 2011) та гендером - (Koc, Vignoles, 2018; Leonardi, Frecker, Scheim, Kives, 2018; McCormick,Witelson, 1991). Йдеться про суб'єктивне благополуччя лесбійок, гомосексуалів, бісексуалів й трансгендерів/ЛГБТ (Suppes, Napier, van der Toorn, 2019); про вікові гендерні відмінності суб'єктивного благополуччя - у дитинстві (Green, 1987), отроцтві (Leonardi, Frecker, Scheim, Kives, 2018), юнацтві (Woodford, Kulick, Sinco, Garvey, Hong, 2018) та дорослості (Grasso, Goldhammer, Funk, King, Reisner, Mayer, Keuroghlian, 2019) тощо.

Суб'єктивне благополуччя (як вид психологічного благополуччя) пов'язане 3 особистісними і соціальними змінними. Суб'єктивне благополуччя, як образ та категоріальна структура в індивідуальній свідомості людини, перманентно зумовлює нові аспекти його переживання, що відображено в численних дослідженнях. Психологічне благополуччя «оцінюється самою людиною з позицій ії цінностей і цілей. Оскільки останні завжди індивідуальні, то універсальної для всіх структури благополуччя не може бути. В такому разі, доцільно вивчати фактори, що впливають на суб'єктивне відчуття задоволеності (екзистенціальне переживання ставлення до власного життя)» (Сердюк, 2017, С.130 ). 


\section{Питання психології}

Отже, суб'єктивне благополуччя є динамічною когнітивно-емоційною оцінкою людини якості свого життя в цілому та окремих його сфер, зокрема. Така оцінка формується на основі об’єктивних чинників, які $є$ сприйнятими і засвоєними особистістю із урахуванням іii індивідуально-типологічних особливостей. Суб'єктивне благополуччя як оцінка особистістю себе та свого життя є тим персональним конструктом, який має вияв у трьох формах - афективній, когнітивній та поведінковій. Гармонічність переживання негативних і позитивних емоцій, уявлення про своє життя та окремі його сфери як такі, що відповідають ідеалу свого існування (задоволеність життям), формують відкриту, динамічну (через зміну умов життя та, відповідно, переформування уявлення про нього й відповідні емоційні реакції), однак сталу (оскільки залежить від особистісних особливостей) систему образів себе та свого життя.

Йдеться про: а) оцінку свого життя, його якості (де благополуччя трактується у широкому сенсі), поєднуючи соціальні, фізичні, психологічні аспекти особи (Lyubomirsky, Sheldon, Schkade, 2005; Seligman, Csikszentmihalyi, 2000); б) задоволеність життям (Huebner, Gilman, 2006), в) конструювання коректних адаптивних форм поведінки 3 метою підвищення задоволеності життям (Lyubomirsky, Sheldon, Schkade, 2005), г) з'ясування природи та чинників незадоволеності життям (Huebner, Gilman, 2006) тощо.

Мета статті розкрити особливості задоволеності життям як складової суб'єктивного благополуччя осіб із гомосексуальною орієнтацією.

Методи дослідження. У дослідження використано шкалу «Задоволеність життям» (Е. Дінер) та дисперсійний аналіз. Інтерпретацію рівнів за методикою Е. Дінера узагальнено у три рівні, а саме: високий склали два рівні - «найвищою мірою задоволений», «дуже задоволений»; середній - «біль-менш задоволений», «злегка задоволений»; низький - «злегка незадоволений», «незадоволений». Всього у дослідженні взяло участь 180 осіб, які мають постійне місце проживання на території України. 3 них 88 осіб - чоловіки та 92 особи - жінки, віком від 18 до 50 років. Вибірку було розподілено за критерієм сексуальної орієнтації респондентів на дві групи по 90 осіб у кожній: гетеросексуальна (40 чоловіків та 50 жінок) та гомосексуальна (48 геїв та 42 лесбійки).

Результати i обговорення. Поняття задоволеності життям найчастіше пов'язують iз суб'єктивним благополуччям особистості. У трикомпонентній концепції суб'єктивного благополуччя його зміст складають: задоволеність життям, позитивні та негативні емоції. Суб'єктивне благополуччя буде тим вищим, чим більше особа переживає позитивні емоції і чим менше переживає негативні емоції, тим більшою є задоволеність власним життям, яка не $\epsilon$ суто емоційною оцінкою, а містить і когнітивні судження (Ендрюс, 1986).

Йдеться про когнітивно-афективну оцінку ситуації, що склалася (як благополучної, так і неблагополучної). Когнітивна складова оцінки є оцінкою різниці між існуючим станом справ та ідеальною ситуацією. Афективна складова оцінки має вияв у позитивних і негативних емоціях та станах, які пов'язані зі щоденним досвідом. Дослідники визначають задоволеність життям як суб'єктивну, когнітивну та рефлексивну оцінки, тобто думку про те, наскільки все було і залишається благополучним (Селігман, 1998; Аргайл, 1990). Зокрема, щастя вважають станом переживання задоволеності життям в цілому, загальною рефлексивною оцінкою людини свого минулого i теперішнього, а також частоту та інтенсивність ії позитивних емоцій. 3'ясовано залежність щастя від соціальних зв'язків, значущими серед яких $\epsilon$ психологічна підтримка, яка надходить від найближчого середовища особистості. Насамперед, йдеться про шлюбні відносини, внутрішньосімейні та близькі дружні зв'язки, які значущі соціальні зв’язки (Аргайл, 1990).

Вченими виведено, так звану, формулу щастя (Щ): $\mathrm{C}=\mathrm{I}+\mathrm{O}+\mathrm{B}$ (щастя = індивідуальний діапазон + зовнішні обставини + вольовий контроль), де «І» - це індивідуальний діапазон, генетично 


\section{Питання психології}

зумовлений рівень щастя, що залишається відносно стабільним протягом життя і до якого особа повертається після більшості значущих подій в іiі житті. Цей складник визначає щастя приблизно на $50 \%$; «О» - це зовнішні обставини (родина, діти, релігія, буденна діяльність, які визначають щастя на $10 \%$; «В» - це фактори, що піддаються вольовому контролю особистості (це усвідомлені дії, та ті дії, які потребують зусиль, тобто ті, які особа може вибрати для себе), які визначають щастя на 40\% (Селігман, 1998). Внутрішній комфорт, духовний розвиток, задоволеність якістю життя дають змогу людині відчувати себе щасливою, а у змісті суб'єктивного благополуччя особистості це має вияв у емоційно позитивному супроводі дійсності.

Задоволеність життям $є$ змінною, що фіксує особливості та рівень суб'єктивної

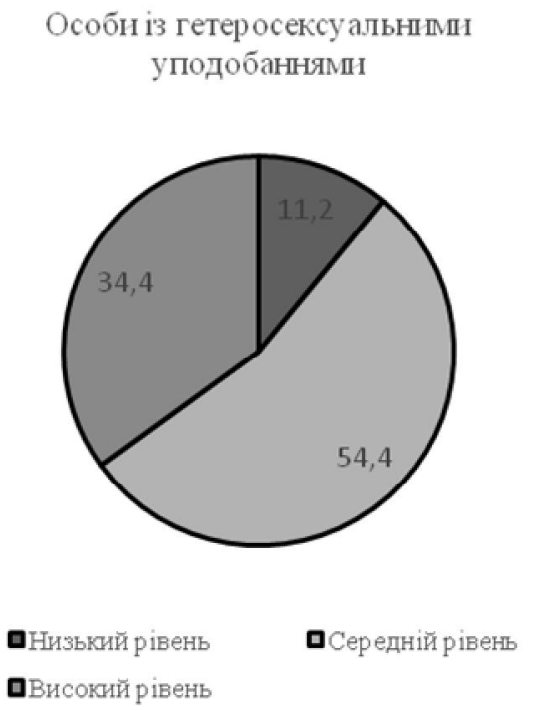

інтепретації особистістю її власного життя як благополучного або не благополучного. За критерієм задоволеності життям (за шкалою Е. Дінера, рис.1.1) більшість респондентів мають середній рівень задоволеності життям: 54,4\% осіб з гетеро сексуальною та 76,6 \% осіб із гомосексуальною орієнтацією. Низький рівень задоволеності життям характерний для представників обох груп однаковою мірою - $11,2 \%$ та $12,2 \%$ відповідно. Високий рівень задоволеності життям характерний для $11,2 \%$ осіб із гомосексуальними уподобаннями та $34,4 \%$ осіб із гетеросексуальними уподобаннями. 3 усім тим, у осіб, що мають високий результат за шкалою задоволеності життям, залишаються певні сфери життєдіяльності, досягнення в яких їх не достатньо задовольняють.

Рис. 1.1. Порівняння рівня задоволеності життям в осіб із

гомосексуальними $(\mathrm{n}=90)$ та гетеросексуальними $(\mathrm{n}=90)$ уподобаннями $(\%)$

Такі незадоволення переважно стають мотивацією для роботи над собою. Ці особи адекватно сприймають реальні та потенційні труднощі і готові вживати відповідних заходів для їх подолання. Відомо, що суб'єктивне благополуччя особистості детермінується процесом соціалізації, яка визначає риси, специфіку, різноманітність життя особистості, що сприяє чи не сприяє її благополуччю.

Середні значення рівня задоволеності життям відрізняються в осіб із гетеросексуальними уподобаннями $(\mathrm{M}=6,98)$
Особн і'з гомосексу альнимн уподобаннямп

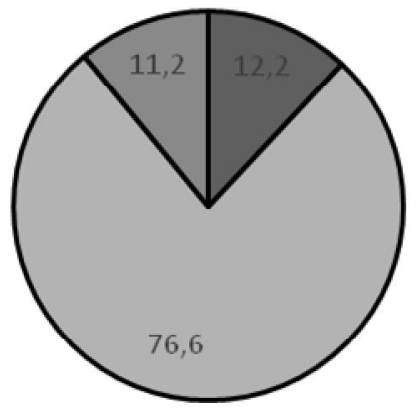

口Низький рівень

व Середній рівенг

口Високий рівень та в осіб із гомосексуальними уподобаннями $(\mathrm{M}=5,03)$. У ході проведення статистичного аналізу (дисперсійного аналізу ANOVA за критерієм Левіна та попарною перевіркою груп досліджуваних за допомогою tкритерію Стьюдента) не виявлено значущість у відмінностях між досліджуваними групами $(\mathrm{F}=0,003 ; \quad \mathrm{p}<0,01)$. Таким чином, респонденти 3 гетеро- і гомосексуальними уподобаннями в цілому мають однакові шанси щодо задоволеності життям, вважаючи його близьким до бажаного образу. Більшість 


\section{Питання психології}

життєвих обставин вони переважно сприймають як сприятливі для себе. Гетерота гомосексуальність як вияв різних гомо- та гетероідентичностей $є$ підгрунтям для продуктивного існування особи в різних сферах життєдіяльності.

Зазначимо, що відчуття суб'єктивного благополуччя не завжди співпадає із об'єктивним благополуччям особистості (тобто 3 перебуванням іiі у субкультурних середовищах - сталих i динамічних, явних $\mathrm{i}$ прихованих, номінальних і референтних), яке оцінюється за відповідними соціальними критеріями. Йдеться, насамперед, про особисті досягнення людини, iï спрямованість, поведінку та діяльність, а також про внесок, що нею самою здійснюється у відповідну субкультуру.

Водночас, порівняння по групах респондентів із гомосексуальною та гетеросексуальною орієнтаціями за критерієм задоволеності життям (табл. 1.) має такий розподіл: а) високий рівень задоволеності життям властивий гетерожінкам (40\%) та геям (25\%). Ці особи проявляють активний інтерес до життя, цілеспрямованість, послідовність у досягненні цілей, мають загальний позитивний фон настрою; б) середній лесбійкам $(71,4 \%)$ та геям $(64,5 \%)$; в) низький - гетерочоловікам (15\%) та лесбійкам (14,2\%).

Таблиця 1 .

Розподіл по групах респондентів із гомосексуальною та гетеросексуальною орієнтаціями за критерієм задоволеності життям (\%)

\begin{tabular}{|l|c|c|c|}
\hline $\begin{array}{l}\text { Сексуальна } \\
\text { оріснтація }\end{array}$ & Рівень & Середній & Високий \\
\hline Гетерочоловіки & 15 & 57,5 & 27,5 \\
\hline Гетерожінки & 8 & 52 & 40 \\
\hline Геї & 10,4 & 64,5 & 25 \\
\hline Лесбійки & 14,2 & 71,4 & 14,2 \\
\hline
\end{tabular}

3 усім тим, представникам кожної з груп властиві окремі універсальні аспекти задоволеності життям, а саме: а) гетерочоловіки - наявність друзів, улюбленої роботи, цілей та наявності можливостей їхнього досягнення, можливість відпочинку; б) геї - соціальна взаємодія, яка надає відчуття комфортного існування, можливість вести бажане духовне і культурне життя, наявність улюбленої роботи; в) гетерожінки - сім'я, відсутність проблем зі здоров'ям, улюблена робота, можливість відпочити; г) лесбійки комфортна соціальна взаємодія, сім'я, відсутність проблем зі здоров'ям, можливість вести бажане духовне і культурне життя.

Висновки. Психологічне благополуччя (як інтегральний показник) суб'єктивно виражається у відчутті щастя, задоволеності особистості своїм життям і собою. Отримані

результати свідчать, що задоволеність i благополуччя людини складається iз суб'єктивного емоційного ставлення до змістовної та змістової сторін подій та явищ іiі життя. При цьому більшість осіб зазначають про суттєві відмінності між наявним та омріяним ідеалом життя. За показником загального рівня задоволеності життям не встановлено суттєвих відмінностей між особами із гомо- та гетеросексуальною орієнтаціями. Виходячи 3 цього, можна стверджувати, що сексуальні уподобання особистості не $\epsilon$ визначальними щодо иii загальної задоволеності своїм життям. Показники інших змістових компонентів суб'єктивного благополуччя, їх зв'язки із задоволеністю життям у гомо- та гетеросексуальних осіб й стануть предметом наших подальших пошуків.

\section{Список використаних джерел}

1. Пахоль Б. Е. Субъективное и психологическое благополучие: современные и классические подходы, модели и факторы / Б. Е. Пахоль // Украинский психологический журнал. - 2017. - № 1 (3). - С. 80 $-104$. 


\section{Питання психології}

2. Сердюк Л. 3. Структура та функція суб’єктивного благополуччя / Л. 3. Сердюк // Актуальні проблеми психології: Інститут психології імені Г. С. Костюка НАПН України. - Том XVII. - № 4 (11). - С. $124-133$.

3. Чиксентмихайи М. Поток: психология оптимального переживания / М. Чиксентмихайи. - М. : Смысл: Альпина нон-фикшн, 2011.-461 с.

4. Шамионов Р. М. Психология субъективного благополучия личности / Р. М. Шамионов. Саратов: Изд-во Саратовского университета, 2004. - 174 с.

5. Andrews F. M. Stability and change in levels and structure of subjective well-being / F. M. Andrews // Social Indicators Research. - Vol. 25. 1991. - P. 1-30.

6. Cathcart-Rake E. J. Acquisition of sexual orientation and gender identity data among NCI / CathcartRake E.J., Zemla T., Jatoi A., Weaver K.E., Neuman H., Kazak A. E., Carlos R., Gansauer L., Unger J. M., Pajewski N. M., Kamen C. Cancer Community Oncology Research Program practice groups, 2019. - №125(8):1313-1318. doi: $10.1002 /$ cncr.31925.

7. Deci T. L. The "what" and "why" of goal pursuits: Human needs and the self-determination of behavior / T. L. Deci, R. M. Ryan // Psychological Inquiry. 2000. - Vol. 11.- P. 227-268.

8. $\quad$ Grasso C. Required Sexual Orientation and Gender Identity Reporting by US Health Centers: FirstYear Data. / C. Grasso, H. Goldhammer, D. Funk, D. King, S. L. Reisner, K. H. Mayer, A. S. Keuroghlian, J. Am // Public Health. - 2019. - 109(8):1111-1118. doi: 10.2105/AJPH.2019.305130.

9. Green R. The "sissy boy syndrome" and the development of homosexuality / R. Green // New Haven. - CT: Yale University Press, 1987.

10. Huebner E. S. Students who like and dislike school / E. S. Huebner, R. Gilman // Applied Quality of Life Research. - 2006. - Vol.1. - P. 139-150.

11. Joronen K. Familial contribution to adolescent subjective well-being / K. Joronen, P. Astedt-Kurki // International Journal of Nursing Practice, 2019. - Vol.11. - P. 125-133.

12. Leonardi M. Reproductive Health Considerations in Sexual and or Gender Minority Adolescents./ M. Leonardi, H. Frecker, A. I. Scheim, S. J. Kives // Pediatr Adolesc Gynecol. - 2019. - 32(1):15-20. doi: 10.1016/j.jpag.2018.09.010.

13. Lyubomirsky S. Pursuing happiness: The architecture of sustainable change / S. Lyubomirsky, K. M. Sheldon, D. Schkade // Review of General Psychology, 2005. - Vol. 9. - P.111-131.

14. McCormick, C. M. A cognitive profile of homosexual men compared to heterosexual men and women / C. M. McCormick, S. F. Witelson // Psychoneuroendocrinology. - 1991 - - №16. - P. 459-473.

15. Ryff C. D. The contours of positive human healt / C. D. Ryff, B. Singer. Psychological Inquiry, 1998. - Vol. 9. - P. 719-727.

16. Seligman M. Positive psychology / M. Seligman, M. Csikszentmihalyi // American psychologist. 2000. - Vol. 55. - № 1. - P. 5-14. - Режим доступа: http://dx.doi.org/10.1037/0003-066X.55.1.5

17. Serdiuk, L. Psychological well-being of future specialists in the integrated educational environment and the factors of its formation / L. Serdiuk // Social welfare : interdisciplinary approach. - 2011. - №1(1). - P. 44-51.

18. Suppes A. The Palliative Effects of System Justification on the Health and Happiness of Lesbian, Gay, Bisexual, and Transgender / A. Suppes, J.Napier, J. van der Toorn // Individuals Pers Soc Psychol. - 2019. Bull. 45(3). P. 372-388. doi: 10.1177/0146167218785156.

19. Woodford M. R. LGBTQ policies and resources on campus and the psychological wellbeing of sexual minority college students / M. R. Woodford, A. T. Kulick, J. C. Garvey, B. R. Sinco, J. S. Hong // Psychology of Sexual Orientation and Gender Diversity. - 2018. - № 5(4). - P. 445-456.

\section{References}

1. Pahol B. E. (2017) Sub'ektivnoe i psihologicheskoe blagopoluchie: sovremennyie i klassicheskie podhodyi, modeli i faktoryi. Ukrainskii psihologicheskii zhurnal [Subjective and psychological well-being: modern and classical approaches, models and factors]. 1(3). 80-104 (in Ukraine).

2. Serdiuk L. Z. (2017) Struktura ta funktsiia subiektyvnoho blahopoluchchia. Aktualni problemy psykholohii: Instytut psykholohii imeni H. S. Kostiuka NAPN Ukrainy [The structure and function of subjective well-being]. Tom XVII. 4 (11). 124-133 (in Ukraine).

3. Chiksentmihayi M. (2011) Potok: psihologiya optimalnogo perezhivaniya [Flow: The Psychology of Optimal Experience]. M. Smyisl: Alpina non-fikshn. 461 (in Russia).

4. Shamionov R. M. (2004) Psihologiya sub'ektivnogo blagopoluchiya lichnosti [Psychology of subjective well-being of the individual]. Saratov: Izd-vo Saratovskogo universiteta. 174 (in Russia). 


\section{Питання психології}

5. Andrews, F. M. (1991). Stability and change in levels and structure of subjective well-being. Social Indicators Research. Vol. 25.1-30.

6. Cathcart-Rake E. J., Zemla T., Jatoi A., Weaver K. E., Neuman H., Kazak A. E., Carlos R., Gansauer L., Unger J. M., Pajewski N. M., Kamen C. Cancer (2019). Acquisition of sexual orientation and gender identity data among NCI Community Oncology Research Program practice groups. 125 (8). 1313-1318. doi: 10.1002 / cncr.31925.

7. Deci T. L., Ryan R. M. (2000). The "what" and "why" of goal pursuits: Human needs and the selfdetermination of behavior. Psychological Inquiry. Vol. 11.227-268.

8. Grasso C., Goldhammer H., Funk D., King D., Reisner S. L., Mayer K. H., Keuroghlian A. S., Am J. (2019). Required Sexual Orientation and Gender Identity Reporting by US Health Centers: First-Year Data. Public Health. 109 (8). 1111-1118. doi: 10.2105 / AJPH.2019.305130.

9. Green, R. (1987). The "sissy boy syndrome" and the development of homosexuality. New Haven, CT: Yale University Press.

10. Huebner, E. S., Gilman R. (2006). Students who like and dislike school. Applied Quality of Life Research. Vol.1.139-150.

11. K. Joronen \& P. Astedt-Kurki (2019). Familial contribution to adolescent subjective well-being. International Journal of Nursing Practice. Vol.11.125-133.

12. Leonardi M., Frecker H., Scheim A. I., Kives S. J. (2019). Reproductive Health Considerations in Sexual and or Gender Minority Adolescents. Pediatr Adolesc Gynecol. 32 (1). 15-20. doi: 10.1016 / j.jpag.2018.09.010.

13. S. Lyubomirsky, K.M. Sheldon, D. Schkade (2005). Pursuing happiness: The architecture of sustainable change. Review of General Psychology. Vol. 9. 111-131.

14. McCormick, C. M., Witelson, S. F. (1991). A cognitive profile of homosexual men compared to heterosexual men and women. Psychoneuroendocrinology. 16. 459-473. 727.

15. Ryff C. D., Singer B. (1998) The contours of positive human healt. Psychological Inquiry. Vol. 9. 719

16. Seligman M. E. P., Csikszentmihalyi M. (2000). Positive psychology. American psychologist. Vol. 55. 1. 5-14. - Access mode: http://dx.doi.org/10.1037/0003-066X.55.1.5

17. Serdiuk, L. (2011). Psychological well-being of future specialists in the integrated educational environment and the factors of its formation. Social welfare: interdisciplinary approach. 1 (1). 44-51.

18. Suppes A., Napier J. L., van der Toorn J. (2019). The Palliative Effects of System Justification on the Health and Happiness of Lesbian, Gay, Bisexual, and Transgender Individuals Pers Soc Psychol Bull. 45 (3). 372 388. doi: $10.1177 / 0146167218785156$.

19. Woodford, M. R., Kulick, A. T., Garvey, J. C., Sinco, B. R., Hong, J. S. (2018). LGBTQ policies and resources on campus and the psychological wellbeing of sexual minority college students. Psychology of Sexual Orientation and Gender Diversity. 5 (4). 445-456.

\section{Резюме \\ Камшеко К. І. аспирант, кафедра соииальной психологии факультета психологии, КНУ имени Тараса Шевченко \\ Траверсе Т. М. доктор психологічних наук, дочент, КНУ Тараса Шевченко \\ УДОВЛЕВОРЁННОСТЬ ЖИЗНЬЮ ЯК СОСТАВЛЯЮЩАЯ СУБЪЕКТИВНОГО БЛАГОПОЛУЧИЯ ЛЮДЕЙ С ГОМОСЕСУАЛЬНОЙ ОРИЕНТАЦИЕЙ.}

Понятие удовлетворенности жизнью связывают с субъективным благополучием личности, положительными и отрицательными эмоциями. Речь идет о субъективном эмоциональном отношении к содержательной и смысловой стороне событий и явлений жизни лич с гомо- и гетеросексуальной ориентачиями.

Ключевые слова: идентичность геев и мужчин; субъективное благополучие лесбиянок и гомосексуалов; субъективное благополучие гетеросексуалов; удовлетворенность жизнью.

\section{Summary}

Kamsheko K. I. graduate student, department of social psychology faculty of psychology, Taras Shevchenko National University of Kyiv, of Ukraine

Traverse T. M. doctor of psychological sciences, docent Taras Shevchenko National University of Kyiv, of Ukraine 


\section{Питання психології}

\section{SATISFACTION BY LIFE AS TREASURE SUBJECTIVE PROSPERITY OF PERSONS WITH}

HOMOSEXUAL ORIENTATION

Introduction. Coming cardinally the new future products the newest transformations of society, that by the turn, related to the change of cultural kodas, legitimizacieyu of other subcultures and associations, valued changes, and others like that It all predetermines substantial changes in experiencing of the life, psychological prosperity or neblagopoluchchya a man. The problem of subjective prosperity, his influence, on the different aspects of life of personality acquires the special actuality for persons with a homosexual orientation.

Purpose - to expose the features of satisfaction life as a constituent of subjective prosperity of persons with a homosexual orientation.

Methods. 177 persons which have a permanent habitat on territory Ukraine took part in research. From them a 91 person - men and 86 persons are women, in age from 18 to 50 years. The main rozmezhovuyuchim criterion of selection is a sexual orientation of respondentiv, namely: 63 persons - geteroseksuali (26 men and 37 women), 114 persons - gomoseksuali (65 men and 49 women).

Originality. The table of contents of subjective prosperity is made: satisfaction by life, positive and negative emotions. Satisfaction life is by a variable which represents features and level of subjective perception personality of it own life as happyor not happy.

After the criterion of satisfaction life is set such levels: and) low-peculiar for the representatives of both groups in an identical degree (about 10\%); bi) middle - incident to majority (2/3) of persons with a homosexual orientation and half of persons with a heterosexual orientation; in) high-peculiar 11\% respondentiv with homosexual tastes and 35\% respondentiv with heterosexual tastes. Mean value of level of satisfaction for persons with heterosexual tastes makes $M=6,98$ ( $n=90)$ life, and for persons with homosexual tastes $-M=5,03$ ( $n=90)$. Thus, respondenti with heterosexual tastes on the whole have a higher level of satisfaction life.

Conclusion. Among all respondentiv, the persons of sex of men characterize the life more optimistically. By comparison to women, men are anymore inclined to consider the life near to the ideal, and to consider circumstances more favourable. After the index of general level of satisfaction by life of meaningful differences between persons from gomo- and heterosexual orientations it is not discovered. Consequently, it is possible to assert that sexual tastes of personality are not determining in relation to its general satisfaction by the life.

Keywords: identity of geiv and men; subjective prosperity of lesbiyok and gomoseksualiv; subjective prosperity of gomo- and geteroseksualiv; satisfaction by life.

Автори заявляють об відсугності конфлікту інтересів.

Recelved/Поступила: 18.12. 20 